\title{
MENINGKATKAN KEMAMPUAN MEMBACA PERMULAAN MELALUIMEDIA BALOK HURUF PADA KELOMPOK B TK NEGERI PEMBINA BANTUL
}

\author{
Oleh: \\ Syari'ati Masyithoh, \\ PPG SM-3T PG PAUD UNY 2016 \\ syariatimasyithoh gmail.com
}

\begin{abstract}
Abstrak
Penelitian ini bertujuan untuk meningkatkan kemampuan membaca permulaan melalui balok huruf pada kelompok B1 TK Negeri Pembina Bantul. Kemampuan membaca permulaan yang ditingkatkan ialah menyebutkan bunyi huruf yang ada didalam kata, menyebutkan kata dengan jelas, dan menyusun huruf membentuk kata yang memiliki makna. Jenis penelitian ini adalah Penelitian Tindakan Kelas kolaboratif yang menggunakan model Kemmis \& Mc Taggart. Subjek penelitian ini adalah anak kelompok B1 TK Negeri Pembina Bantul sebanyak 17 anak yang terdiri dari 5 anak perempuan dan 12 anak laki-laki. Metode pengumpulan data dilakukan melalui observasi dan dokumentasi. Teknik analisis data dilakukan secara deskriptif kuantitatif dan kualitatif. Hasil penelitian menunjukkan bahwa kemampuan membaca permulaan dapat meningkat setelah diberikan tindakan dengan menggunakan balok huruf yang diberi penyangga sehingga memudahkan anak untuk mencoba menyusun huruf dengan cara diputar dan memberikan tantangan pada anak yang dilakukan secara bersamaan dengan teman menyerupai perlombaan, serta pemberian reward secara kongkret yakni menggambar bintang pada punggung telapak tangan anak.

Kata kunci: kemampuan membaca permulaan, media balok huruf, kelompok B.

\section{Abstract}

The research was aimed at improving early reading skill of group B1 students in TK Negeri Pembina Bantul using letter bars. The specific early reading skills intended to be improved are the skill of pronouncing letters of a word, pronouncing words clearly, and arranging letters into meaningful words. The study is categorized into Action Research (AR) using the model proposed by Kemmis and Mctaggart. Subjects of the research were 17 students of TK Negeri Pembina Bantul in group B1 comprising 5 girls and 12 boys. Data was obtained using observation and documentation. The data was then analyzed both in quantitative and qualitative domain descriptively. The research result showed that the treatment was able to improve the students' early reading skills. The letter bars was supported by prop thus it eased the students when arranging letter bars by rotating them. The other finding showed that it gave challenge to the students in the form of group work, and also the reward treatment concretely by drawing stars on their hands.
\end{abstract}

Key words: early reading skill, letter bars media, group B

\section{PENDAHULUAN}

Pendidikan Anak Usia Dini (PAUD) merupakan upaya pembinaan yang ditujukan kepada anak sejak lahir sampai usia enam tahun, yang dilakukan melalui pemberian rangsangan pendidikan untuk membantu pertumbuhan dan perkembangan jasmani dan rohani anak, agar memiliki kesiapan dalam memasuki pendidikan selanjutnya (Permendikbud Nomor 146
Tahun 2014). Undang-Undang Sistem Pendidikan Nasional Nomor 20 Tahun 2003 Pasal 28 menyatakan "Pendidikan Anak Usia Dini pada jalur formal berbentuk Taman Kanak-kanak (TK), Raudhatul Athfal (RA), atau bentuk lain yang sederajat". TK terdiri dari usia 4-6 tahun. Di Indonesia dikelompokkan ke dalam dua kelompok yakni kelompok A 
usia 4-5 tahun dan kelompok B usia 5-6 tahun.

Anak usia dini disebut dengan masa keemasan (the golden ages) yang merupakan masa dimana anak mulai peka untuk menerima berbagai stimulasi dan pendidikan. Adapun aspek-aspek perkembangan anak usia dini yang perlu di stimulasi antara lain aspek Nilai Agama dan Moral (NAM), kognitif, bahasa, fisik motorik, sosial emosional, dan seni. Keenam aspek tersebut perlu dikembangkan secara porposional agar anak tumbuh dan berkembang sesuai dengan tahapan usianya.

Salah satu perkembangan yang perlu distimulasi pada anak adalah perkembangan bahasa. Perkembangan bahasa meliputi bahasa ekspresif dan reseptif. Salah satu komponen yang menjadi prioritas adalah membaca permulaan. Berdasarkan wawancara dengan guru harapan orang tua ialah anak dapat membaca setelah lulus dari TK untuk melanjutkan jenjang pendidikan selanjutnya yakni Sekolah Dasar.

Menurut Piaget (Tadkiroatun Musfiroh, 2005: 9) perkembangan bahasa anak TK masih bersifat egosentrik dan selfexpressive, yaitu segala sesuatu yang masih berorientasi pada diri sendiri. Perkembangan bahasa dapat dipakai sebagai tolak ukur kecerdasan anak dikemudian hari. Interaksi dengan orang yang lebih tua memiliki peran penting dalam mendukung perkembangan bahasa anak usia dini Bredekamp \& Coople (Tadkiroatun Musfiroh, 2005: 84).

Karakteristik perkembangan bahasa menurut Stephanie Muller (2005: 16) adalah membaca buku favorit dan membaca kembali cerita secara sederhana, mendengarkan cerita dan mengungkapkan tulisan yang dikenal, menggunakan kosakata deskriptif untuk menjelaskan dan mempelajari sesuatu, mengenal huruf, memasangkan huruf dan bunyi, memasangkan dan mengenal bunyi awal dan bunyi akhir, memahami konsep tulisan, memasangkan kata yang diucapkan secara verbal dengan kata dan tulisan, membunyikan kata-kata tertentu (menghubungkan fonem), mengenal katakata dasar yang sering dipakai, menulis huruf alfabet tertentu, menuliskan nama, serta mengenal dan menghitung suku kata dalam kata-kata verbal. Sedangkan Nurbiana Dhieni, dkk (2005: 9.6) mengungkapkan bahwa karakteristik perkembangan bahasa tentang keaksaraan pada anak usia 5-6 tahun yaitu mendengarkan, berkomunikasi lisan, memiliki perbendaharaan kata dan mengenal simbol-simbol yang melambangkannya untuk persiapan membaca dan menulis. Jadi dapat disimpulkan bahwa karakteristik perkembangan bahasa tentang keaksaraan pada anak usia 5-6 tahun yaitu menyebutkan simbol-simbol huruf yang dikenal sebagai persiapan membaca dan menulis, memahami konsep tulisan, dan memasangkan kata yang diucapkan secara verbal dengan kata maupun tulisan atau gambar.

Pengenalan membaca permulaan merupakan kegiatan yang perlu diberikan pada anak. Melalui kegiatan membaca permulaan, anak akan mengenal simbolsimbol huruf, bentuk huruf, bunyi huruf, dan membaca kata. Hal tersebut sesuai dengan Permendiknas Nomor 137 Tahun 2014 yang menyebutkan bahwa perkembangan bahasa dalam lingkup keaksaraan pada usia 5-6 tahun yaitu menyebutkan simbol-simbol huruf yang dikenal, memahami hubungan antara bunyi dan bentuk huruf, membaca serta menulis namanya sendiri.

Membaca permulaan adalah suatu kesatuan kegiatan yang terpadu mencakup beberapa kegiatan seperti mengenali huruf dan kata-kata, menghubungkannya dengan bunyi, maknanya, serta menarik kesimpulan mengenai maksud bacaan (Nurbiana Dhieni, 2005: 5.5). Membaca permulaan menurut Slamet Suyanto (2005: 165) ialah mulai dari tulisan yang anak lihat di sekitar lingkungannya, lalu anak mulai mengidentifikasi berbagai jenis 
huruf. Selanjutnya anak mulai menghubungkan huruf-huruf tersebut dengan huruf-huruf yang ada di media cetak lainnya. Anak mulai memahami bahwa huruf-huruf tersebut memiliki fungsi dan makna. Kemudian anak akan belajar merangkai dan menggunakan huruf-huruf tersebut ketika akan belajar alfabet.

Tanda-tanda anak yang mempunyai kesiapan membaca menurut Nurbiana Dhieni (2005: 9.3) yaitu dapat memahami bahasa lisan, dapat mengucapkan kata dengan jelas, dapat mengingat kata-kata, dapat mengucapkan bunyi huruf, sudah menunjukan minat membaca, dan dapat membedakan suara atau bunyi dan objek dengan baik.

Kegiatan membaca memiliki peranan penting dalam kehidupan anak antara lain ialah menambah kosakata baru anak, mengembangkan imajinasi dan kreativitas anak, serta menstimulasi perkembangan kemampuan komunikasi anak. (http://www.bimba-aiueo.com/12-manfaatmembaca-bagi-anak/).

Cochrane et al dalam Slamet Suyanto (2005: 168-169) menyebutkan bahwa terdapat lima tahap perkembangan kemampuan membaca pada anak, yaitu:

\section{Tahap Magis (Magical Stage)}

Pada tahap ini anak mulai menyukai bacaan, menganggap bacaan itu penting, sering menyimpan bacaan yang disenangi, dan suka membawa buku kesukaannya. Pada tahap ini orang tua atau guru dapat menstimulasi dengan membacakan buku cerita bergambar, menyediakan buku-buku yang menarik, tas atau tempat lainnya untuk menyimpan dan membawa buku favoritnya.

\section{Tahap Konsep Diri (Self Concept Stage)}

Pada tahap ini anak memandang dirinya sudah dapat membaca (padahal belum). Anak pura-pura membaca buku kemudian menerangkan isi atau gambar kepada anak lain seakan ia sudah dapat membaca. Orang tua dan guru dapat memberikan stimulasi dengan membacakan bacaan lain kepada anak, ajak ke toko buku atau perpustakaan dan beri kesempatan kepada anak untuk memilih buku-buku yang anak suka untuk dibacakan.

\section{Tahap Membaca Peralihan (Bridging Reading Stage)}

Anak mulai mengingat huruf atau kata yang sering dijumpai. Stimulasi yang dapat dilakukan ialah dengan menyediakan berbagai macam bacaan dengan ukuran huruf yang besar, alfabet, dan permainan huruf untuk bermain serta belajar merangkai huruf.

\section{Tahap Membaca Lanjut (Take-off Reader Stage)}

Anak mulai sadar akan fungsi bacaan dan cara membacanya. Mulai tertarik dengan berbagai huruf atau bacaan yang ada di lingkungannya. Misalnya, dengan membaca kata pada papan iklan, membaca huruf-huruf yang ada di bungkus makanan, kardus, dan seterusnya. Tahap ini muncul pada usia 5 tahun. Stimulasi yang dapat dilakukan ialah dengan mengajak anak untuk membaca apa saja tulisan yang ada di lingkungannya (environmental print) dengan cara mengejanya, membaca juduljudul artikel koran yang ukurannya besar dengan mengejanya.

\section{Tahap Membaca Mandiri (Independent Reader Stage)}

Strategi pengembangan kemampuan membaca permulan pada anak di TK menurut Ehri \& Mc. Cormick dalam Carol Seefeldt \& Barbara A. Wasik (2006: 330331) belajar abjad adalah komponen hakiki dari perkembangan membaca. Anak yang mulai memperhatikan huruf cetak pada halaman buku, maka mereka mulai tertarik pada huruf-huruf yang membentuk kata. Anak yang bisa menyebutkan dan mengenal huruf-huruf pada daftar abjad akan lebih mudah belajar membaca. Anak mulai sering membaca buku sendirian, mencoba memahami makna dari bacaan, menghubungan apa yang dibaca dengan pengalamannya. Stimulasi yang dapat 
dilakukan ialah dengan menyediakan berbagai macam bacaan bergambar warnawarni dengan ukuran huruf relatif besar agar anak tertarik membaca secara mandiri.

Strategi bahasa seutuhnya memiliki tujuan yaitu memberikan pengalaman banyak pada anak dengan membaca dan kata tertulis, sehingga anak dapat mengetahui makna dari kata tersebut. Strategi ini kata-kata tidak dianalisi menjadi bagian-bagian, tetapi dipelajari sebagai unit-unit utuh sebagai bagian dari seluruh teks. Apabila seorang anak menjumpai sebuah kata yang tidak diketahuinya, anak didorong untuk menerka kata tersebut berdasarkan konteks dan teka-teki gambar. Anak-anak diajarkan untuk melihat seluruh kata di dalam konteks makna kalimat ketimbang memfokuskan pada masing-masing huruf dan bunyi di dalam satu kata Carol Seefeldt \& Barbara A. Wasik (2006: 341). Sedangkan strategi fonik menekankan pada kode atau berbasis kode yaitu anak diajarkan bagaimana huruf-huruf abjad dan kelompok huruf diterapkan pada bunyibunyi di dalam kata. Penekanan pendekatan fonik menolong anak-anak untuk mengembangkan strategi-strategi sehingga mereka bisa mengartikan kata-kata yang baru dijumpai (Carol Seefeldt \& Barbara A. Wasik, 2006: 341).

Pengembangan

kemampuan membaca anak usia dini berhubungan langsung dengan tingkat bimbingan orang dewasa (guru dan orangtua) dalam menggunakan bahasa dan menekankan hubungan tulisan dengan abjad, kata, dan pesan (Stephanie Muller, 2006: 8). Kegiatan membaca tidak bisa lepas dari peran guru dan orangtua sebagai orang terdekat bagi anak dalam menstimulasi kemampuan membaca permulaan pada anak, dengan membentuk lingkungan yang menyenangkan dan nyaman, sehingga kegiatan membaca menjadi kegiatan pilihan yang menyenangkan bagi anak.

Kegiatan membaca permulaaan perlu dikenalkan di tingkat TK dengan menggunakan media dan metode pembelajaran yang tepat sesuai dengan tahap perkembangan anak. Persoalan yang terpenting untuk mengajarkan membaca permulaan adalah strategi yang perlu dilakukan agar anak menganggap membaca sebagai kegiatan yang menarik dan menyenangkan dengan media yang kreatif sesuai dengan tahap perkembangan anak. Salah satu strategi yang dapat dilakukan untuk meningkatkan kemampuan membaca permulaan pada anak adalah dengan menggunakan media pembelajaran yang menarik dan kreatif serta dikemas dalam kegiatan yang menyenangkan. Dengan demikian, akan tercipta lingkungan belajar yang produktif tanpa memberikan tekanan pada anak. Hal tersebut dilakukan agar anak tidak mengalami kesulitan untuk melanjutkan jenjang pendidikan berikutnya yaitu Pendidikan Sekolah Dasar.

Menurut Arief S. Sadiman (2009: 17) secara umum media pendidikan mempunyai manfaat yaitu memperjelas penyajian pesan agar tidak terlalu bersifat verbalitas, mengatasi keterbatasan ruang, waktu dan daya indera, serta mengatasi sikap pasif anak saat kegiatan pembelajaran berlangsung.

Manfaat media pembelajaran menurut Muhyidin, dkk (2014: 108) yaitu menghindari terjadinya verbalisme, membangkitkan motivasi belajar, menarik perhatian murid, mengatasi keterbatasan ruang, waktu, dan ukuran, serta mengaktifkan murid dalam kegiatan belajar untuk mengeksplorasi suatu objek.

Media pembelajaran bermanfaat untuk memudahkan siswa belajar memahami sesuatu yang mungkin sulit atau menyederhanakan sesuatu yang kompleks Slamet Suyanto (2005: 38). Sementara itu, Hamalik dan Sadiman dalam Nurbiana Dhieni (2005: 10.3) mengemukakan manfaat media dalam proses pembelajaran yaitu memperjelas penyajian pesan dan mengurangi verbalitas saat pembelajaran, memperdalam pemahaman anak terhadap materi pelajaran, memperagakan sesuatu yang abstrak ke sesuatu yang kongkret, mengatasi keterbatasan ruang, waktu, dan 
daya indra, mendorong anak untuk berperan aktif dalam proses belajar, mengatasi sifat unik setiap anak yang diakibatkan oleh lingkungan yang berbeda, memberi variasi dalam proses belajar mengajar, memberikan kesempatan pada anak didik untuk mereview pelajaran yang diberikan, serta memperlancar pelaksanaan kegiatan belajar mengajar dan mempermudah tugas mengajar guru.

Berdasarkan pendapat di atas dapat disimpulkan bahwa media pembelajaran sangat bermanfaat untuk mendukung proses pembelajaran baik untuk guru maupun peserta didik. Media memberikan kemudahan bagi guru saat menyampaikan materi dengan bervariasi dan menarik sehingga memunculkan keaktifan anak dalam mengikuti proses pembelajaran.

Media yang digunakan guru saat proses pembelajaran untuk meningkatkan kemampuan membaca lebih sering menggunakan media kartu huruf, buku, dan LKA (Lembar Kerja Anak). Guru memberikan kartu huruf kepada anak kemudian anak menyebutkan hurufnya dan membaca kata yang dibentuk. Meskipun demikian sebagian anak masih belum mencapai perkembangan yang baik dalam membaca permulaan.

Guru sebaiknya berusaha mencari berbagai media yang sesuai dengan perkembangan anak untuk meningkatkan kemampuan membaca. Strategi pembelajaran yang tepat ialah berpusat pada anak artinya anak terlibat aktif didalam pembelajaran sehingga akan lebih menimbulkan kebermaknaan dalam memperoleh pengalaman sehingga ilmu yang didapat mampu terserap dengan baik oleh anak.

Penggunaan media balok huruf dirasa lebih efektif untuk meningkatkan kemampuan membaca permulaan karena media tersebut mudah dibuat dan dapat memanfaatkan barang bekas. Balok huruf merupakan media yang terbuat dari kertas karton berukuran $5 \mathrm{~cm}$ x $5 \mathrm{~cm}$, yang dilengkapi dengan huruf dan gambar pada setiap sisinya. Cara menggunakan balok huruf adalah dengan dibolak-balik atau diputar sesuai dengan huruf yang diinginkan, sehingga memudahkan anak untuk menggunakan dengan mencoba-coba menyusun huruf membentuk kata yang sesuai dengan gambar yang dipilih. Balok huruf merupakan media yang menarik bagi anak karena terdapat gambar-gambar yang berwarna, ukuran huruf yang jelas, bisa dibolak-balik atau diputar, memungkinkan anak untuk mencoba-coba secara berulangulang, dan mampu menunjukkan pokok permasalahan karena disertai dengan gambar yang bersifat konkret. Balok huruf disertai dengan gambar karena gambar memiliki kekuatan besar dalam merespon otak anak. Anak akan mudah memahami kata-kata yang dipelajarinya dengan melihat gambar. Di TK Negeri Pembina Bantul balok huruf sudah ada di kelas namun belum pernah digunakan, sehingga diharapkan menjadi sesuatu yang menarik. Selain itu, media ini diharapkan mampu memberi pengalaman menarik bagi anak dalam meningkatkan kemampuan membaca permulaan pada kelompok B1 di TK Negeri Pembina Bantul. Oleh karena itu peneliti mengambil judul "meningkatkan kemampuan membaca permulaan melalui media balok huruf pada kelompok B di TK Negeri Pembina Bantul”.

\section{METODE PENELITIAN Jenis Penelitian}

Jenis penelitian yang digunakan dalam penelitian ini adalah penelitian tindakan kelas (PTK) kolaboratif yaitu penelitian yang dilakukan melalui kerjasama kemudian diperiksa secara kritis melalui refleksi demokratik dan diologis Suwarsih Madya (2011: 51). Penelitian tindakan kelas ialah penelitian yang dilakukan oleh guru di kelasnya sendiri dengan cara merencanakan, melaksanakan, dan merefleksikan tindakan secara kolaboratif dan partisipatif Wijaya Kusumah (2012: 9). Penelitian tindakan kelas memiliki karakteristik yaitu berupa tindakan yang berguna untuk memperbaiki proses belajar mengajar. Penelitian 
tindakan ini merupakan pemberian tindakan-tindakan alternatif yang dibuat oleh peneliti yang dalam pelaksanaannya berkolaborasi dengan guru kelas kemudian diujicobakan dan dievaluasi apakah penelitian tindakan tersebut dapat memecahkan masalah pembelajaran yang dihadapi.

\section{Waktu dan Tempat Penelitian}

Penelitian ini dilaksanakan di dalam kelas TK Negeri Pembina Bantul pada kelompok B1. Tindakan penelitian dilaksanakan pada semester I tahun ajaran 2016/2017 dan dilakukan saat kegiatan inti.

\section{Target/Subjek Penelitian}

Subjek dalam penelitian ini adalah anak-anak kelompok B1 yang berjumlah 17 anak yaitu 12 anak laki-laki dan 5 anak perempuan.

\section{Prosedur Penelitian}

Penelitian ini menggunakan model Kemmis \& Mc Taggart. Menurut Wijaya Kusumah (2010: 20), model Kemmis \& Mc Taggart merupakan pengembangan dari konsep dasar yang diperkenalkan oleh Kurt Lewin. Perbedaannya terletak pada komponen acting (tindakan) dengan observing (pengamatan) dijadikan sebagai satu kesatuan. Konsep PTK menurut Kemmis \& Mc Taggart terdiri dari empat komponen yaitu perencanaan, tindakan dan pengamatan, serta refleksi. Tahapan pada setiap Siklus kegiatan dengan desain PTK model Kemmis \& Mc Taggart, dapat dilihat pada gambarkan berikut ini.

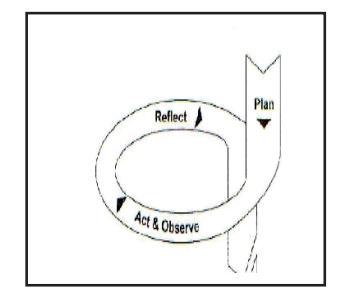

Gambar 1

Siklus PTK menurut Kemmis \& Mc Taggart (Wijaya Kusumah \& Dedi Dwitagama, 2012: 21)

\section{Data, Instrumen, dan Teknik Pengumpulan Data}

Teknik pengumpulan data yang digunakan adalah observasi dan dokumentasi. Instrumen untuk pengumpulan data yaitu checklist dan dokumentasi.

\section{Teknik Analisis Data}

Teknik analisis data yang digunakan dalam penelitian ini adalah deskriptif kuantitatif dan kualitatif. Deskripsi kuantitatif digunakan untuk menganalisis data berupa angka. Data yang didapat dijadikan sebagai acuan dalam perencanaan tindakan (Siklus) selanjutnya Adapun rumus yang digunakan (Ngalim Purwanto (2006: 102).

$$
N P=\frac{\mathrm{K}}{\mathrm{SM}} \times 100
$$

Keterangan:

NP : Nilai persen yang diharapkan

$\mathrm{R}$ : Skor mentah yang diperoleh siswa

SM : Skor maksimum ideal dari tes yang Bersangkutan

100 : Bilangan tetap

Deskriptif kualitatif dimaksudkan untuk menggambarkan hasil pengamatan peneliti dan kolaborasi dengan guru kelas tentang kemampuan membaca permulaan melalui media balok huruf.

\section{HASIL PENELITIAN DAN PEMBAHASAN}

Jenis penelitian yang telah dilakukan yaitu Penelitian Tindakan Kelas (PTK) kolaboratif yang terdiri dari dua Siklus. Pelaksanaan tindakan pada Siklus I dilaksanakan sebanyak tiga kali pertemuan pada masing-masing kemampuan membaca permulaan yang ditingkatkan dan Siklus II sebanyak empat kali pertemuan. Siklus II merupakan perbaikan secara keseluruhan dari Siklus I mengenai peningkatan kemampuan membaca permulaan anak. Hasil secara keseluruhan kemampuan membaca permulaan anak mengalami peningkatan. Berikut ini tabel rekapitulasi peningkatan kemampuan membaca permulaan anak pada kelompok B1 dari kondisi awal sampai Siklus II:

Tabel 1. Rekapitulasi Hasil Kemampuan Membaca Permulaan Sebelum Tindakan, Siklus I, dan Siklus II 


\begin{tabular}{ccccc}
\hline No & Kriteria & $\begin{array}{c}\text { Kondisi } \\
\text { Awal }\end{array}$ & Siklus I & Siklus II \\
\hline 1. & BB & $\begin{array}{c}3 \\
(17,64 \%)\end{array}$ & $\begin{array}{c}0 \\
(0 \%)\end{array}$ & $\begin{array}{c}0 \\
(0 \%)\end{array}$ \\
\hline 2. & \multirow{2}{*}{$\mathrm{MB}$} & $\begin{array}{c}8 \\
(47,05 \%)\end{array}$ & $\begin{array}{c}3 \\
(17,64 \%)\end{array}$ & $\begin{array}{c}0 \\
(0 \%)\end{array}$ \\
\hline 3. & \multirow{2}{*}{$\mathrm{BSH}$} & $\begin{array}{c}4 \\
(23,52 \%)\end{array}$ & $\begin{array}{c}8 \\
(47,05 \%)\end{array}$ & $\begin{array}{c}3 \\
(17,64 \%)\end{array}$ \\
\hline \multirow{2}{*}{4.} & \multirow{2}{*}{$\mathrm{BSB}$} & $\begin{array}{c}2 \\
(11,76 \%)\end{array}$ & $\begin{array}{c}6 \\
(35,29 \%)\end{array}$ & $\begin{array}{c}14 \\
(82,35 \%)\end{array}$ \\
\hline
\end{tabular}

Berdasarkan tabel di atas kemampuan membaca permulaan anak kelompok B1 mengalami peningkatan dari kondisi awal. Pada kriteria berkembang sangat baik mengalami peningkatan dari kondisi awal berjumlah 2 anak (11,76\%) menjadi 6 anak $(35,29 \%)$ pada Siklus I. Kemudian meningkat pada Siklus II yakni menjadi 14 anak (82,35\%). Jadi kelompok B1 mengalami peningkatan pada kriteria berkembang sangat baik kemampuan membaca permulaan sejumlah 70,59\%.

Pada penelitian Siklus I masih ada lima anak yang mengalami kesulitan dalam membedakan huruf yang hampir sama seperti " $b$, d; n, m", masih ada dua anak yang suaranya lirih atau pelan sehingga menyulitkan peneliti untuk mendengarnya, dan terdapat tiga anak yang masih terbalik dalam meletakkan susunan huruf dan masih banyak mendapatkan bantuan dari guru. Perilaku yang ditunjukkan oleh guru diperkuat dengan pendapat Bond \& Dykstra (Slamet Suyanto, 2005: 165) yang menyatakan bahwa mengenal huruf dan merangkai huruf menjadi kata menjadi kesulitan tersendiri bagi anak karena terdapat beberapa huruf yang mirip tetapi bacaannya berbeda. Huruf $\mathrm{m}$ dan $\mathrm{w}$ bagi anak tidak jauh berbeda, namun cukup menyulitkan anak karena bunyinya jauh berbeda. Bagi anak huruf dibalik kemana saja tetap sama jenis dan bunyinya. Anak TK yang mengenal huruf lebih cenderung memiliki kemampuan membaca lebih baik.

Hambatan-hambatan yang dialami pada Siklus I dicatat kemudian dijadikan sebagai acuan untuk mencari solusi dan memperbaiki pada pelaksanaan Siklus II. Beberapa solusi yang dilakukan oleh peneliti dan guru sebagai rekan kolaborasi dalam penelitian ini yaitu media balok huruf dibuat menjadi satu set dengan diberi penyangga sehingga satu balok dengan balok lainnya tidak terpisah dan sesuai dengan urutan. Media balok huruf dibuat warna di semua sisi tidak hanya huruf dan tepi saja. Kegiatan pembelajaran di Area Bahasa dibuat seperti suasana lomba dengan dua anak menggunakan media dan dua anak lainnya memberikan motivasi serta semangat jika ada anak yang sendiri maka ia dipersilahkan untuk memilih teman lain untuk menyusun balok huruf secara bersamaan. Pemberian reward berupa bentuk bintang yang di gambarkan pada punggung telapak tangan anak.

Pelaksanaan Siklus II yaitu dengan menambahkan penyangga pada balok huruf, kegiatan dibuat seperti perlombaan di dalam Area sehingga anak-anak merasa tertantang dan pemberian reward menunjukkan adanya peningkat secara signifikan pada kemampuan membaca permulaan anak kelompok B1. Meskipun mengalami peningkatan namun pada Siklus II masih ada satu anak yang lebih sering mengganggu teman dan masih sulit untuk berkonsentrasi serta tiga anak belum mencapai kriteria keberhasilan dikarenakan masih kesulitan dalam membedakan huruf dan menyusun huruf membentuk kata sesuai dengan gambar yang dipilih. Mereka belum memiliki kesiapan untuk membaca meskipun anak sudah cukup umur. Hal ini sesuai dengan pendapat Crawley dan Mountain dalam Farida Rahim (2007: 2) yang mengatakan bahwa membaca pada tingkat awal dapat diberikan di TK namun hal ini tergantung dari kesiapan anak. Berapapun usia anak TK sudah mampu untuk membaca asalkan anak sudah mempunyai kesiapan untuk membaca sehingga saat guru mengajarkan anak akan lebih mudah untuk menerima apa yang diajarkan oleh guru. Adanya perbaikan pada Siklus II diperoleh hasil bahwa anak tidak mengalami kesulitan lagi dalam menyusun huruf karena media terdapat penyangga sehingga memudahkan anak untuk memutar huruf tanpa terbalik hurufnya. Selain anak lebih jelas saat 
membaca huruf yang ada pada balok huruf, anak juga menjadi lebih aktif dalam pembelajaran, dan dapat memberikan variasi dalam proses pembelajaran membaca yang lebih efektif. Hal ini sesuai dengan pendapat Hamalik dan Sadiman dalam Nurbiana Dhieni (2008: 10.4) dan dari Nana Sudjana \& Ahmad Rivai (2005: 2) yang mengatakan bahwa dengan menggunakan media dapat mengatasi sikap pasif anak sehingga anak tidak hanya mendengarkan guru tetapi juga mengamati dan melakukan serta media mampu memberikan variasi dalam pembelajaran.

Pelaksanaan tindakan pada Siklus II berjalan sesuai dengan perencanaan dan mencapai kriteria keberhasilan yang telah ditetapkan oleh peneliti. Peningkatan kemampuan membaca permulaan ini dipengaruhi oleh pembelajaran membaca menggunakan media balok huruf. Sebab, dengan bermain balok huruf pembelajaran membaca permulaan menjadi lebih mudah, menyenangkan dan lebih menarik perhatian anak. Media balok huruf yang digunakan oleh anak dilengkapi dengan gambar dan bentuk tiga dimensi yang dapat diputar mengkinkan anak untuk dapat mencoba secara berulang-ulang. Hal ini sesuai dengan pendapat Arif Sadiman (1986: 29) yang menyatakan bahwa gambar mempunyai sifat yang konkret dan realistis, sehingga mampu menunjukkan pokok masalah dibandingkan dengan media verbal.

Kemampuan membaca permulaan anak kelompok B1 yaitu menyebutkan huruf yang ada di dalam kata, menyebutkan kata dengan jelas, dan menyusun huruf menjadi kata yang bermakna mengalami peningkatan. Secara keseluruhan kemampuan membaca permulaan mengalami peningkatan sejumlah 14 anak $(82,35 \%)$. Dengan demikian, jumlah tersebut telah mencapai indikator keberhasilan yang telah ditentukan, sehingga penelitian dihentikan pada Siklus II.

Jadi melalui media balok huruf yang diberi penyangga dan dilakukan seperti perlombaan di dalam area baca tulis dapat meningkatkan kemampuan membaca permulaan pada kelompok B1 TK Negeri Pembina Bantul.

\section{SIMPULAN DAN SARAN Simpulan}

Berdasarkan hasil penelitian dan pembahasan yang dikemukakan, maka diperoleh kesimpulan bahwa melalui media balok huruf yang diberi penyangga memudahkan anak untuk mencoba menyusun huruf dengan cara diputar dan kegiatan yang dilakukan secara bersamaan dengan teman menyerupai perlombaan, serta pemberian reward secara konkret yakni menggambar bintang pada punggung telapak tangan anak dapat meningkatkan kemampuan membaca permulaan pada kelompok B1 TK Negeri Pembina Bantul.

Peningkatan kemampuan membaca permulaan dapat terlihat secara optimal dari hasil data observasi dan dokumentasi yang diperoleh pada setiap Siklusnya. Peningkatan dari pra tindakan ke Siklus I sebesar 24\% dan dari Siklus I ke Siklus II mengalami peningkatan sebesar $47,06 \%$. Anak yang berada pada kriteria Berkembang Sangat Baik sebelum tindakan berjumlah 2 anak (11,76\%), pada Siklus I berjumlah 6 anak $(35,29 \%)$ dan pada Siklus II berjumlah 14 anak (82,35\%). Sehingga kegiatan pembelajaran membaca permulaan ini dikatakan berhasil karena $80 \%$ dari 17 anak kelompok B1 TK Negeri Pembina Bantul telah mencapai indikator keberhasilan yang telah ditetapkan.

\section{Saran}

Berdasarkan hasil penelitian, peneliti mengemukakan beberapa saran sebagai berikut:

\section{Guru}

Guru dapat memanfaatkan media balok huruf yang sudah tersedia di kelas untuk meningkatkan kemampuan membaca permulaan, sehingga tidak hanya sebagai pelengkap media di area bahasa.

\section{Bagi Peneliti Selanjutnya}


Penelitian mengenai kemampuan membaca permulaan ini sebagian menggunakan bahan dasar barang bekas. Oleh karena itu menjadi motivasi bagi peneliti selanjutnya untuk melengkapi penelitian ini dengan menggunakan bahan lain untuk membuat balok huruf, sehingga kemampuan membaca permulaan akan lebih meningkat dengan cara yang kreatif dan menyenangkan.

\section{DAFTAR PUSTAKA}

Arief S, dkk. (2009). Media pendidikan pengertian, pengembangan, dan pemanfaatannya. Jakarta: Rajawali Press.

Arif Sadiman. (1986). Media Pendidikan. Jakarta: Raja Grafindo.

Farida Rahim. (2007). Pengajaran Membaca di Sekolah Dasar. Jakarta: PT Bumi Aksara.

Menteri Pendidikan dan kebudayaan. (2014). Peraturan Menteri Pendidikan dan Kebudayaan Republik Indonesia Nomor 146 tahun 2014 tentang Standar Isi Tingkat Pencapaian Perkembangan.

Menteri Pendidikan dan Kebudayaan. (2014). Peraturan Menteri Pendidikan dan Kebudayaan Republik Indonesia Nomor 137 tahun 2014 tentang Standar Nasional Pendidikan Anak Usia Dini.

Mueller, S. (2006). Panduan belajar membaca jilid 1. (Terjemahan Teuku Kemal Husein). Jakarta: Erlangga.

Muhyidin, dkk. (2014). Ensiklopedia pendidikan anak usia dini anak usia dini. Yogyakarta: Insan Madani.

Muhyidin, dkk. (2014). Ensiklopedia pendidikan anak usia dini metode \& media pembelajaran. Yogyakarta: Insan Madani.

Nana Sudjana \& Ahmad Rivai. (2002). Media Pengajaran. Bandung: Sinar Baru.

Ngalim Purwanto. (2006). Prinsip-prinsip \& Tekhnik Evaluasi Pengajaran. Bandung: PT. Remaja Rosdakarya.

Nurbiana Dhieni, dkk. (2005). Metode pengembangan bahasa. Jakarta: Universitas Terbuka.

Ranis. (2013). Pengertian Membaca. Diakses dari http://www.bimbaaiueo.com/12-manfaat-membacabagi-anak/) pada tanggal 23 Juli 2016, jam 18.00 WIB.

Seefeldt, C. \& Wasik, B. A. (2008). Pendidikan anak usia dini menyiapkan anak usia tiga, empat, dan lima tahun masuk sekolah. (Terjemahan Pius Nasar). Jakarta: PT Indeks.

Slamet Suyanto. (2005). Konsep dasar pendidikan anak usia dini. Jakarta: Direktorat Jenderal Pendidikan Tinggi Direktorat Pembinaan Pendidikan Tenaga Kependidikan dan Ketenagaan Perguruan Tinggi.

Slamet Suyanto. (2005). Pembelajaran untuk anak TK. Jakarta: Direktorat Jenderal Pendidikan Tinggi Direktorat Pembinaan Pendidikan Tenaga Kependidikan dan Ketenagaan Perguruan Tinggi.

Suntrock, J.W. (2007). Perkembangan anak. Edisi 8. (Terjemahan Mila Rachmawati). Jakarta: Erlangga.

Suwarsih Madya. (2011). Penelitian tindakan action research. Bandung: Alfabeta. 
Tadkiroatun Musfiroh. (2005). Bercerita untuk anak usia dini. Jakarta: Direktorat Jenderal Pendidikan Tinggi Direktorat Pembinaan Pendidikan Tenaga Kependidikan dan Ketenagaan Perguruan Tinggi.

Tadkiroatun Musfiroh. (2005). Bermain sambil belajar dan mengasah kecerdasan. Jakarta: Direktorat Jenderal Pendidikan Tinggi Direktorat Pembinaan Pendidikan Tenaga Kependidikan dan Ketenagaan Perguruan Tinggi.

Wijaya Kusumah \& Dedi Dwitagama. (2010). Mengenal Penelitian Tindakan Kelas. Jakarta: PT. Indeks. 